\title{
THE ICONOGRAPHY OF ECUMENICAL COUNCILS AND THE BYZANTINE (NEW ROMAN) POLITICAL PHILOSOPHY
}

Mariyan STOYADINOV*

\begin{abstract}
The Byzantine Church is the realm where Christian and Roman universality have met. According to the political philosophy of the Byzantine Empire the role of the Emperor is to express the visible unity of a specific two dimensional (spiritual-political) structure of social life. The Iconography of the Ecumenical councils is an illustration of this role of the Emperor according to Byzantine political philosophy. At the same time the iconographic composition is a replica of the Icon of Pentecost illustrating the role of the Holy Spirit in the council. The text analyzes some historical facts and their reflection on the iconography of the Ecumenical councils. At the same time there are references to the contemporary theology and practice of synodality.
\end{abstract}

Keywords: Church, council, icon, emperor, ecumene, synodality

\section{Introduction}

The theme of the Ecumenical Councils is presented relatively rarely in the hymnography and iconography of the Church. According to contemporary liturgical practice there are three Sundays in the annual cycle dedicated to the Holy Fathers of the Councils ${ }^{1}$. At the same time

* PhD, Associated Professor, Veliko Tarnovo University (Faculty of Orthodox Theology), Veliko Tarnovo, Bulgaria

${ }^{1}$ The $7^{\text {th }}$ Sunday after Passover (between Ascension and Pentecost) - the Fathers of the Council in Nicaea (First Ecumenical); The $6^{\text {th }}$ Sunday after Pentecost - the Fathers of the six Ecumenical Councils; and the $4^{\text {th }}$ Sunday after Ascension - the Fathers of the Seventh Ecumenical Council. 
the iconographic theme of Ecumenical Councils is not presented in large numbers of churches nowadays.

The earliest known image is the cycle of six Ecumenical Councils, depicted - until the early $8^{\text {th }}$ century - on the walls of the imperial palace in Constantinople ${ }^{2}$. In the period of iconoclasm as government policy in Byzantiun this cycle, among many others, was totally destroyed.

In response to the controversial religious policy of the Byzantine emperors, the cycle of Ecumenical councils has been depicted in the ancient basilica of St. Peter in Rome and in the narthex of St. Peter's church in Naples. Since 843 when the victory of Orthodoxy in Byzantium was proclaimed solemnly this cycle - of seven Ecumenical councils now - more often begins to be painted on the walls of churches in the Empire and also in the new Christian kingdoms in the East. Remarkably, these images are painted in churches directly related to the emperor or local ruler - Tzar or King. Such cases are those in the close Byzantine commonwealth - Georgia in $12^{\text {th }}$ century (Gelati Monastery), Bulgaria in $13^{\text {th }}$ century (St Peter and Paul church, Tarnovo) and Serbia in $13^{\text {th }}$ and $14^{\text {th }}$ century (monasteries in Kosovo and Metohija) - and later in Russia after $16^{\text {th }}$ century (Vologda, Moscow Kremlin etc.)

The transition of these iconographic scenes from the Imperial Palace to the churches erected or supported by the rulers, is evidence of the specific message about the order in the universe, which stands as the foundation of the New Roman (Byzantine) understanding of the Church and Empire.

\section{Hypothesis}

The subject of this text is the iconological interpretation of universality or ecumenicity and of the Catholicity of the Church. The iconography of the Ecumenical Councils warrants such an interpretation as they simultaneously show both the catholicity of the Church - in its responsibility for the verbal formulation of dogma - and the universality of the Church in its two dimensions - ecclesiastical and

2 Н. В. КвливидзЕ, “Вселенский собор (Иконография)”, (N. V. KVLIVIDZE, "Ecumenical Council. Iconography"), in Православная Энциклопения, т. 9, Москва, 2005, с. 570. 
imperial. In this sense, iconographic scheme contains and implies an answer to the question: "what distinguishes the Ecumenical Council from any other?" Also, it indirectly answers the question why nearly thirteen centuries after Nicea 787 the Church has no council, which can be called 'ecumenical'.

So, if we can formulate a hypothesis, it would be: the iconography of the Ecumenical Councils illustrates a meeting and coexistence of two universes (or between two universalisms) - Roman and Church. Formally. Formally this meeting is incidental as far as it remains a unique phenomenon in the history of the Church, not done before Nicaea (325 AD), or after the political schism in 800 - when "the Roman" empire of Charles the Great appeared. As such it is not only an illustration but the hermeneutic key to the theme of Ecumenical Councils to date.

And there is one other dimension that correspond to the specific universality of the Church as a task - to be the Entrance of 'all nations' (Matt. 28:193) to "the coming world ( (Hebr. 2:5) ${ }^{4}$. In fulfilling this task the Empire is no more than an instrument.

Of course, the Church does not "iconify" abstract concepts, such as universality, catholicity, history or theology. She always has as its object a particular person or event.

\section{Description of scenes}

There are not many researchers in this particular field of study, but amongst those few, we especially note Sévérien Salaville ${ }^{5}$, Christopher Walter ${ }^{6}$, Tinatin B. Virsaladze ${ }^{7}$ and Plamen Subev ${ }^{8}$, who

3 The BIBLE references are according New Revised Standard Bible (NRSB). http://www.biblestudytools.com/nrs/ (last accessed 15.04.2017).

${ }^{4}$ Concerning eschatological dimension of the verse cf. the study of Павлин СъБЕВ, $B$ тези последни дни (Pavlin SABEv, In These Last Days), Велико Търново, 2013, с. 106-125.

5 S. SAlaville, "L'iconographie des Sept conciles oekumemiques (Iconography of seven Ecumenical Councils)", Extrait des Echos d'Orient, Paris, 1926.

${ }^{6}$ Christopher WALTER, "The names of Council Fathers at Saint Sozomenus, Cyprus (planches)", in Revue des etudes byzantines, t. 28/1970, p. 189-206.

7 Т. Б. ВИРСАЛАДЗЕ, “Фрагменты древней фресковой росписи главного Гелатского 
published explicit research on the peculiarities of the iconographic compositions in the churches and monasteries in the Byzantine commonwealth. These studies are interesting in view of the how they enter into the detail and the description of the specific characteristics peculiar to each fresco. The value of these studies is even more important in cases with murals already irretrievably lost. This is so in the church Sts. Peter and Paul in Tarnovo (Bulgaria) where six of the original seven councils illustrated were destroyed in 1913 by an earthquake? .

The data published by modern researchers about the scheme of the Ecumenical Council composition correspond with the description of The Painter's Manual ${ }^{10}$ collected by Dionysius of Fourna in the $18^{\text {th }}$ century. Dionysius gives his instruction of how Ecumenical Councils can be depicted in the following way:

\section{$I^{\text {st }}$ Ecumenical Council}

"Building under the illumination of the Holy Spirit and Emperor Constantine sitting in the center on the throne. On both sides of him the hierarchs in clerical attire - Alexander, Patriarch of Alexandria, Eustathius of Antioch, Macarius of Jerusalem, St. Paphnutius the Confessor, and St. Jacob of Nizibia, St. Paul of Neocesareia and other

храма" (T. B.VIRSALADZE, "Fragments of the Ancient Fresco Decoration of the Main Church in Gelati”), in Ars Georgica, No. 5/1959, c. 163-203.

8 Пламен СъБЕВ, 'Вселенските събори' от галерията на църквата 'Рождество Христово' в село Арбанаси (Поглед към функционалните стойности на догматическите решения в контекста на иконографската програма на параклиса, преддверието на параклиса и галерията на храма) (Plamen SABEV, 'Ecumenical Councils' in the gallery of the church 'Nativity of Christ' in Arbanasi'), Известия на Регионален исторически музей - Велико Търново, 2007, XXII, с. 159-178.

9 Ibidem, “Опит за виртуална възстановка на стенописи от XV век в митрополитската църква “Св. св. Петър и Павел” във Велико Търново” (Plamen SABEV, "Virtual reconstruction of the $15^{\text {th }}$ century fresco in the mitropoly church "St. Peter and Paul', Veliko Tarnovo"), in От честния пояс на Богородица до коланчето за рожба. Изследвания по изкуствознание и културна антропология в чест на проф, Елка Бакалова, С., 2010, с. 188-201.

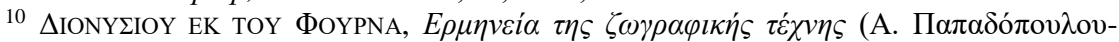

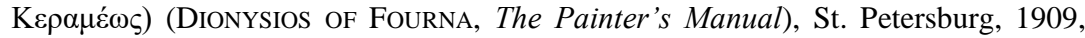
$\sigma \varepsilon \lambda .171-173$. 
saints.

In front of them stands the astonished philosopher and prelate Spyridon of Trimithunt, one hand stretched out to him, and the other squeezing the shingles, from which fire and water come out, and the first one tends upward, and the second one... to the floor. Here Arius stands in priestly vestments and in front of him St Nicholas, formidable and alarmed. Arius' like-minded people sit below all. There is Athanasius the deacon, young, beardless, sitting aside and writing: I believe in the One God the Father, the Almighty... and in the Holy Spirit."

\section{$2^{\text {nd }}$ Ecumenical Council}

"Buildings and over them the Holy Spirit. Emperor Theodosius the Great on the throne and on both sides of him saints - Timothy of Alexandria, Meletios of Antioch, Cyril of Jerusalem, Gregory the Theologian, Patriarch of Constantinople, who writes: and in the Holy Spirit... (to the end), and other saints and fathers. The heretics are sitting apart and talking each other."

\section{$3^{\text {rd }}$ Ecumenical Council}

"Buildings and over them the Holy Spirit. Emperor Theodosius the Younger on the throne, young, with a beard that barely appeared, and on both sides - St. Cyril of Alexandria, Juvenalius of Jerusalem and other saints and fathers. In front of them Nestorius as elderly man in episcopal attire and likeminded heretics."

\section{$4^{\text {th }}$ Ecumenical Council}

"Buildings and over them the Holy Spirit. Emperor Marcian, the elder, on the throne, surrounded by dignitaries who have gold-plated bandages on their heads, and on both sides - Saint Anatolius, Patriarch of Constantinople, Maximus of Antioch, Juvenalius of Jerusalem, Bishops Paschazianus and Lutsensius, and Presbyter Bonifatius - the locum tenens of Leo, Pope of Rome, and other saints and fathers. In front of them stands Dioscorus in the bishop's vestments, and Eutychius, and are in conversation with them."

\section{$5^{\text {th }}$ Ecumenical Council}

"Buildings and over them the Holy Spirit. Emperor Justinian on the throne and on both sides of him - Vigilius Pope of Rome, Eutychius of Constantinople and other fathers. In front of them heretics are standing, being addressed by the fathers." 


\section{$6^{\text {th }}$ Ecumenical Council}

"Buildings and over them the Holy Spirit. Emperor Constantine Pogonat with graying long bifurcated beard, on the throne behind which are visible spearmen, and on either side of it - St. George, Patriarch of Constantinople, and papal locum tenens, Theodore and George, the other fathers. The heretics are addressed by them."

\section{$7^{\text {th }}$ Ecumenical Council}

"Buildings, and over them the Holy Spirit. Emperor Constantine as boy and his mother Irina, and they hold: The Emperor Constantine - the icon of Christ, Irina - the icon of the Mother of God. On both sides of them are sitting St. Tarasius - Patriarch of Constantinople, and the papal locum tenens Peter and Peter the bishops, and other fathers holding icons. Among them one bishop writes: If anyone does not venerate ( $\pi \rho \circ \sigma v v \varepsilon i \bar{l})$ holy icons and the Cross, let him be anathema."

\section{Three observations}

This description of Dyonisius is leading us to the following observations:

The first thing that it impresses is that iconographic schemes follow the iconography of Pentecost. And this is natural, since each of the Church councils is based on the words of "the brothers, both the apostles and the elders" from the Council in Jerusalem, serving as an archetype of each subsequent council: "it has seemed good to the Holy Spirit and to us" (Acts. 15:28). This apostolic formula transferred into Church history and repeated many times is direct evidence for a theological interpretation of the council as a synergistic event. In this event, men are not just actors in political or social events, but are collaborators in God's Economia (Oiкovoría). Of course, not all of the councils in history have "seemed good to the Holy Spirit" and the Church's reception remained impossible for such non-synergic (one sided) events, as the councils in Philipopol in $343 \mathrm{AD}$, the Constantinople "synod of the oak" 403, Ephesus in 449, Hieria in 754 and others. But the latter does not change the premise that it is the gathering of "the apostles and the elders" (Acts. 15: 6) in Jerusalem, as well as every Eucharistic assembly is a precondition for the implementation of the Savior's words: "For where two or three are 
gathered in my name, I am there among them" (Matt. 18:20). Therefore, we do not perform the Eucharist if in the church there are not present at least two persons. In this sense, the meeting in the new Adam, contrasts the images of alienation and disintegration of the old Adam in the same way as the gift of the languages of Pentecost is a counterpoint to the multilingualism of Babylon (Cf. Gen. 11:4-9) ${ }^{11}$.

In the iconography of the Ecumenical Councils, the Catechetical mission of the Church is reflected. The Church extracts its dogmatic teaching from the fullness that Christ shared with His disciples, "I have called you friends, because I have made known to you everything that I have heard from my Father" (John. 15:15). Church in the face of Christ's friends - apostles and fathers - posesess the fullness of everything, the fullness of all the answers, even if the questions are not yet asked. But no one possesses this fullness alone. Every person needs at least other one in order to be part of the Church and a part of the fullness of truth. So, in the following history of the Church baptismal symbols and liturgical orders appeared among the Gospels and the Epistles of the Apostles. From the Father's fullness, through Christ in the Holy Spirit the fathers of the Church - gathered in the Ecumenical Councils - have expressed in the conciliar statements. That is why every image contains the presence of the Spirit and some of the main "trumpets of the Spirit" through whom the dogmatic answers are spoken and written.

The second point that makes an impression is that there is no icon of the Ecumenical Councils without the Ecumenical Emperor in the center of the composition. Every image is an iconographic codification of the place of the Emperor in the Church's ecumenical catholicity.

The latter is in line with Byzantine political philosophy where, at the core of it, is the belief that the Emperor is Vicarious Christi. Later, apparently in the process of political rivalry with Constantinople, the Pope will adopt the same title, replacing his previous one - Vicarious

11 Cf. Holy Pentecost Kontakion (Tone 8): When the most High came down and confused the tongues, / He divided the nations; / But when he distributed the tongues of fire / He called all to unity. I Therefore, with one voice, we glorify the All-holy Spirit! 
Petri $^{12}$. In other words, a council can not be called ecumenical (or universal) if there is no Emperor to convene, support and to implement its decisions.

Ecumenicity is a prerogative of the Emperor not only in a political sense but in the sphere of the Church life, especially since the time of Theodosius the Great (379-395) and his anti-heretical legislation $^{13}$. In this context, calling Ecumenical, the Patriarch of Constantinople (after $6^{\text {th }}$ century) is quite a natural development, since he is Archbishop of the Ecumenical capital of New Rome, where the Emperor of the Ecumennical Empire is residing. In this sense, we have a clear idea of Roman universalism as a Christian universalism.

The Roman Emperor, the Emperor of the Christian universe

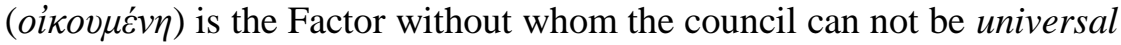

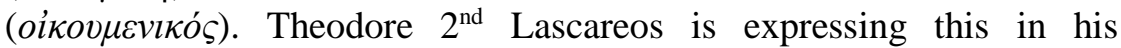
"Apologetic letter to the Bishop of Kotrona against Latins concerning the Holy Spirit". Here we reed one of the most eloquent testimony to the place of Emperor regarding an Ecomenical Council:

"But be aware to that, oh Reverend man: among all previous councils, on which the bishops were gathered, representing their churches, there was no council gathered by the order of any of these bishops, nor the blessed Pope of old Rome, nor patriarch of Constantinople, nor the Pope of Alexandria, nor patriarch of Antioch or Jerusalem or any other, but all councils have been gathered by royal decree. For the Emperor had the power to convene them and without king's command, none of these (councils) would have happened. Maintenance was also from the Emperor and calling and meeting at the required location. And most importantly - when the Reverend (fathers) differed on dogmas, who except the Emperor himself could excel speaking the truth?"14

12 New Commentary on the Code of Canon Law, Ed. John P. Beal, James A. Coriden, Thomas J. Green, NY Paulist Press, 2000, p. 432.

13 Cf. Clyde PhARr, The Theodosian Code and Novels and the Sirmondian Constitutions, A Translation with Commentary, Glossary, and Bibliography. [Princeton]: Princeton University Press, 1952.

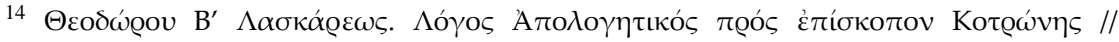

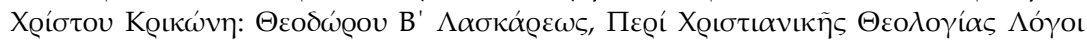
(TheOdORE $2^{\text {nd }}$ LASKAREOS, "Apologetic letter to the Bishop of Kotrona against 
It is paradoxical, but when Theodore II writes these lines, the Roman Empire (B $\alpha \sigma i \lambda \varepsilon i ́ \alpha$ 'P $\omega \mu \alpha i ́ \omega v)$ is reduced to Nikea and its surroundings. Despite the fact that the West usurped the idea of Rome in 800, despite the fact that even Constantinople (New Rome) at that time was the capital of a Latin Empire, the awareness that Emperor is a source of ecumenicity, is an obvious argument even in the Filioque controversy. The East remains Rome-centric not less than the West. But if the West transforms the idea of Rome into a "Rome-centered universal church structure" (impossible without Rome as a visible center of unity), the East does not lag behind in this competition, even if it has lost all objective historical arguments. Rome (or rather New Rome) will continue to be (in a paradoxical way) in Constantinople after 1453 too, after the Ottomans took the City, and the German historiography in 1557 - the name of the Empire ${ }^{15}$.

The iconography of the Ecumenical Councils, as we know, does not remain closed only within the Roman Empire. Patterns of this cycle will be found in all of the individual states that fit their state and church structure within a Roman pattern. Thus, on the one hand, Orthodox Christians in history are underlying the line of continuity with the Councils that defended the faith of the apostles and fathers, ,the faith ...

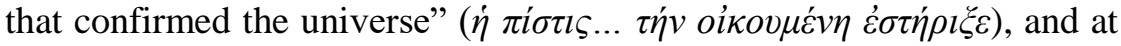
the same time they affirmed "their own Byzantine" political philosophy, in which the Emperor is the center of the iconographic composition. In

Latins concerning the Holy Spirit", in KRIKONIS, Christos, Theodore 2nd Laskareos.

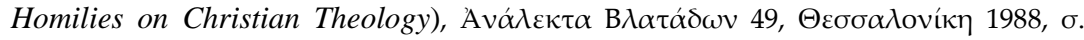

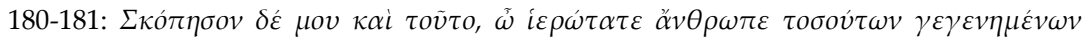

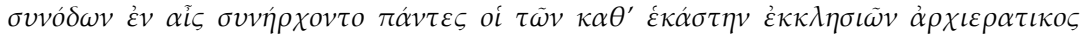

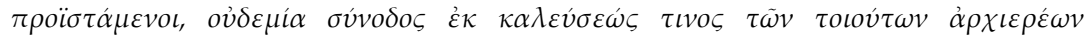

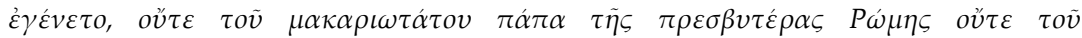

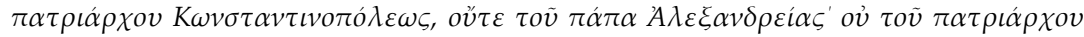

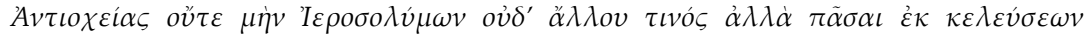

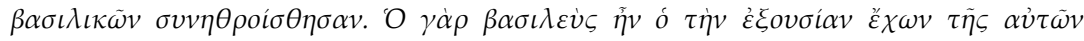

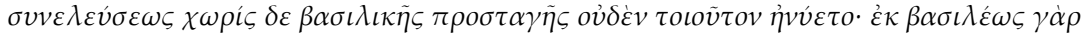

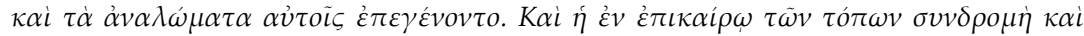

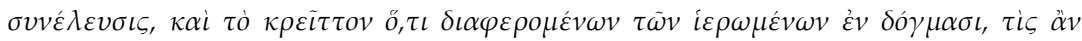

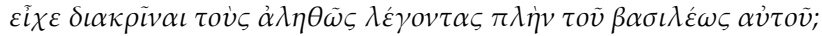

15 At 1557 the German hystorian Jeronimus WoLf published his Corpus Historiae Byzantinae. 
this sense, the iconography of the Ecumenical Councils has a specific "pedagogical" function also, showing a fullness in which the State and the Church are fed in order to be simultaneously a guide of the Church fathers for the honorable attitude towards the state authorities, and at the same time a guidebook for the rulers in their care of the Church. As Lazarev says about the images of the congregations at Gelati Monastery in Georgia: "In images of such type, paraded and solemn, there is a specific accent on the hieratic principle, so precious for the Byzantines" 16.

The third, as evidenced by the iconography of the universal gatherings, is that, at least in the immediate future, we will not be witnessing such an Ecumenical Council. There may, of course, be councils that will express on a global level the universal character of the Church, but this universality will be different from the ecumenity known from the age of the Ecumenical Councils. The Emperor nowadays neither convenes the council nor presides over it, nor applies its decisions as a state policy. Today there is no Emperor. That is why there is no way for the Church nowadays to repeat the iconographic scheme of the Ecumenical Councils. The central figure obviously will be missing.

The idea of Rome today is sheltered in the only institution that has outlived New Rome - the Patriarchate of Constantinople. After the catastrophy of 1453, the Patriarch in Constantinople will receive more power from the Sultans than in the previous centuries. He will become the ethnarch of the entire Rum-millet, will dress in the Emperor's garments and will even obtain the Emperor title of "Despotis". This paradoxical fullness will replace in a way the absence of the Eastern "Vicarius Christi". But along with the Patriarchy, as the guardian of the universal idea and the throne, in recent times we have a conglomerate of at least a dozen parallel micro-universes - autocephalous churches, each with its own "Rome", with their own Statutes "based on the canons" etc. Every local church today is a universe with its own center and diaspora, with overseas and transcontinental eparchies and dioceses. Most rely on the resources of their home-states and none of any other. Gathering a

16 В. Н. ЛАЗАРЕВ, История Византийской живописи (V. N. LAZAREV, The History of Byzantine Painting), Москва „Искусство”, 1986, с. 106. 
council on a universal/ecumenical level of such a variety of national egoisms and "geopolitical question marks" - and all of them to be in agreement - is an obvious problem for anyone who whishes this to happen.

Our modern ecumenicity/universality is more or less a metaphor of the Roman one. If the universality is a task for the Church, or if it has the universality as an inner quality, like its unity, holiness, catholicity, and apostlicity, we should have in the course of history to come to (as in the past history), other models of universality different from the (New) Rome-centric one. But if the Byzantine-type ecumenicity/universalism is the only possible form of ecumenism/universalism, then we should admit that without this imperial universe (plus its Vicarius Christi) we are not able to be a universal Church. Or we just have to acknowledge its non-existence in the reality of current social and political circumstances and to retreat into antiquity or the early Middle Ages as a way of being a kind of "church hipsters" captured in a cultural and historical time warp. I suppose all of the various opinions nowadays have their partisan supporters at least because we have no visible center of our unity. Theologically speaking the issue of our current ecumenicity or universality is an open question and a theological debate on process.

\section{Conclusion}

In the summary, I would like to underline just one detail found the iconography of the seventh Ecumenical Councils. They are dominantly depicted in the narthex or in the church. There, by definition, is the place for historical or illustrative compositions. This is the explanation why in the period till the $15^{\text {th }}$ century they are concentrated in the ruler's patronage of, or erected churches (monasteries) but in the following centuries, especially in the time of the Ottoman yoke in Bulgaria, they appeared in many places ${ }^{17}-$ along with

${ }^{17}$ Cf. И. ГЕРГОВА / Е. ПОПОВА / Е. ГЕНОВА / Н. КЛИСАРОВ, Корпус на стенописите в България om XVIII в. (I. Gergova / E. Popova / E. Genova / N. Klissarov, Corpus of Eighteenth Century Frescos in Bulgaria), C., 2006. Also: Александър КуюмджиЕВ, Стенописите в главната църква в Рилския манастир (Alexander Kuyumdzhiev, The Wall Painting in the Rila Monastery Katholikon), C. 2015, c. 
ancient philosophers sometimes (as is the case in Arbanasi churches in the $16^{\text {th }}$ and $17^{\text {th }}$ centuries) as a historical commemoration of the glorious past. In the hymnography (Throparion, t. 8) we underline the fathers - theologians and confessors - but not the Basileus. I can assume as an argument that hymnography and iconography show us the Church engaged with the Empire, but not dominated by it. The ruins of Christian Empires are behind us but Church is still present. The Byzantine-type ecumenicity/universalism was an important stage in the path of the Church to the future eon. God has allowed in His providence this Roman, universal perspective in the same sense in which he has allowed the ruin of the (New) Rome. Answers should be given not only to the questions of late Antiquity and the early Middle Ages, but also to those that go beyond the human vision. It is for this reason that we can say that the Emporor's ecumenicity is part of our past, but the Ecumenical Councils (and more precisely the conciliar fathers whom we commemorate) are part of our identity as Christians, regardless of the local-Church-universe we live in today. Because - as I mentioned above - in the space of the icons (as in the kingdom of heaven, cf. Matt. 11:12) we have real persons or events, not ideologies, nor even political philosophies.

\section{References}

1. ВИРСАЛАДЗЕ, Т.Б., “ФрагменТЫ древней фресковой росписи главного Гелатского храма" (VIRSALADZE, T. B., "Fragments of the ancient fresco decoration of the main church in Gelati"), in Ars Georgica, 5 1959, c. 163-203.

2. ГЕРГОВА, И. / ПОПОВА, Е. / ГЕНОВА, Е. / КЛИСАРОВ, Н., Корnyс на стенописите в България от XVIII в. (GERGOVA, I. / POPOVA E., I Genova E., / Klissarov, N., Corpus of Eighteenth Century Frescos in Bulgaria), София, 2006.

3. КВЛИВИДЗЕ, Н. В., "Вселенский собор (Иконография) (KVLIVIDZE, N. V., "Ecumenical Council. Iconography"), in Православная Энциклопения, т. 9, Москва, 2005, с. 570.

4. КуЮмджиЕв, Александър, Стенописите в главната иърква в Рилския манастир (KUYUMDZHIEV, Alexander, The Wall Painting in

406-408. 
the Rila Monastery Katholikon), София, 2015, с. 406-408.

5. СъБев, Павлин, В тези последни дни (SABEV, Pavlin, In These Last Days), Велико Търново, 2013, с. 106-125.

6. СъБЕВ, Пламен, 'Вселенските събори' от галерията на църквата ‘Рождество Христово' в село Арбанаси (Поглед към функционалните стойности на догматическите решения в контекста на иконографската програма на параклиса, преддверието на параклиса и галерията на храма) (SABEV, Plamen, 'Ecumenical Councils' in the gallery of the church 'Nativity of Christ' in Arbanasi"), in Известия на Регионален исторически музей Велико Търново, 2007, XXII, с. 159-178.

7. СъБЕВ, Пламен, “Опит за виртуална възстановка на стенописи от XV век в митрополитската църква 'Св. св. Петьр и Павел' във Велико Търново (SABEV, Plamen, Virtual reconstruction of the $15^{\text {th }}$ century fresco in the mitropoly church 'St. Peter and Paul', Veliko Tarnovo), in От честния пояс на Богородица до коланчето за рожба. Изследвания по изкуствознание и културна антропология в чест на проф, Елка Бакалова, София, 2010, с. 188-201.

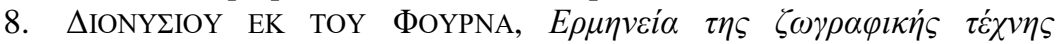
(A.П $\alpha \pi \alpha \delta$ ó $\pi 00 \lambda \circ 0-K \varepsilon \rho \alpha \mu \varepsilon ́ \omega \varsigma$ ) (DIONYSIOS OF FOURNA, The Painter's

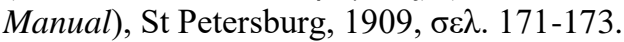

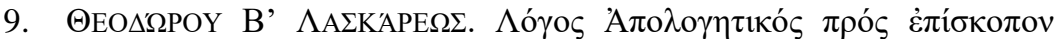

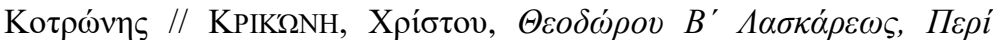

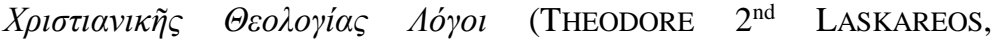
"Apologetic letter to the Bishop of Kotrona against Latins concerning the Holy Spirit" in KRIKONIS, Christos, Theodore 2nd Laskareos. Homilies on Christian Theology), Avád $\varepsilon \kappa \tau \alpha$ B $\lambda \alpha \tau \alpha ́ \delta \omega v \quad 49$,

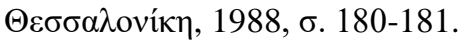

10. New Commentary on the Code of Canon Law, John P. Beal / James A. / Coriden, Thomas J. Green (eds.), NY Paulist Press, 2000, p. 432.

11. Pharr, Clyde, The Theodosian Code and Novels and the Sirmondian Constitutions: A Translation with Commentary, Glossary, and Bibliography. [Princeton]: Princeton University Press, 1952.

12. Salaville, S., "L'iconographie des Sept conciles oekumemiques (Iconography of seven Ecumenincal Councils)", in Extrait des Echos d'Orient, Paris, 1926.

13. WALTER, Christopher, "The names of Council Fathers at Saint Sozomenus, Cyprus (planches)", in Revue des etudes byzantines, t. 28/1970, pp. 189-206. 